\title{
AUTO-FEEDBACK TO IMPROVE ACADEMIC PERFORMANCE
}

\author{
José Manuel Navarro Jover \\ Universitat Politècnica de València (Spain) \\ jnavar@dig.upv.es
}

Received September 2020

Accepted December 2020

\section{Abstract}

This study was carried out on first-year engineering students in the subject of technical drawing, an eminently practical subject that requires the continuous development of spatial vision and also that students should devote time and effort to it from the very beginning. For the study we designed an auto-feedback activity to be applied to the students in the experimental group. The aim was to determine whether the students improved by this means their capacity for self-regulation and ultimately their academic performance. The students included in the experimental group obtained higher scores in the end-of-year self-regulation questionnaire (78.5) than those in the control group (66.47). There was a highly significant correlation $(\mathrm{r}=0.60 ; \mathrm{p}<0.05)$ between the final grade and the class attendance rate. Although the auto-feedback treatment did not directly influence the final grades in the analysis of overall variance, it did have an indirect effect through the attendance variable; the students in the experimental group attended significantly more classes than those in the control group $(82.2 \%$ vs. $68.6 \%$; $<<0.05)$. In fact, a comparison of the average final grades showed that the experimental group obtained significantly higher marks $(6.97 / 10)$ than the control group $(3.8 / 10)$.

Keywords - Auto-feedback, Self-regulation, Academic performance, Undergraduates, Technical drawing.

\section{To cite this article:}

Navarro Jover, J.M.. (2021). Auto-feedback to improve academic performance. Journal of Technology and Science Education, 11(1), 180-193. https://doi.org/10.3926/jotse.1120

\section{Introduction}

A number of studies related to the nature, origin and development of learning processes and strategies have made notable contributions to understanding how to achieve quality in learning (Zimmerman, 2002; García \& Jiménez, 2014; Núñez, Rosário, Vallejo \& González-Pienda, 2013; Boekaerts \& Corno, 2005; Hernández, Rosário, Cuesta, Martínez \& Ruiz, 2006; López, López-Aguado, González \& Fernández, 2012; Rosário, Núñez, González-Pienda, Valle, Trigo \& Guimarães, 2010). As Rosário, Fuentes, Beuchat and Ramaciotti (2016) have pointed out, "The knowledge obtained from the theories and models that explain learning processes has revealed the need to equip students with the right tools for them to get involved and provide an autonomous and self-regulated response to the different educational tasks." Vives-Varela, Durán-Cárdenas, Varela-Ruiz \& Fortoul (2014) carried out a wide-ranging study and analysed self-regulation, including its definition, elements, evaluation methods and advantages, among other factors, and concluded that the self-regulating process has become a common transversal competence for all professionals involved in the health field due to its importance for learning and professional practice. 
Learning self-regulation is an important construct in education. Hernández and Camargo (2017), define it as "the deliberate organization of cognitive, behavioural and environmental activities that lead to successful learning". Self-regulation "refers to learning strategies that students activate when working to achieve the goals they have set themselves" (Panadero \& Alonso-Tapia, 2014). It was previously thought that the teaching-learning process was one-way and the student was simply the receptor of information, a passive subject in the learning process. However, "the development of self-regulating thinking or learning considers the student as the meta-cognitive, motivational and active promoter of his academic performance (Gravini-Donado, Ortiz-Padilla \& Campo-Ternera, 2016). "Students are able to self-regulate their own learning, i.e. plan the strategies to use in every situation, apply them, control the process, detect possible mistakes and thus transfer all of this to a single actuation" (Limón, 2004; Sinatra, 2004). The principal steps in self-regulation can thus be summed up as planning, monitoring and evaluating, and involve three types of skills: cognitive, meta-cognitive and affective."

Hernández and Camargo (2017) point out that the basic purpose of the different self-regulation studies consists of identifying the variables that give the student deliberate control of his academic actions. If university students can be characterised by identifying their dimensions as the self-regulators of their own learning processes, we will be in a position to design or implement formative actions that help them to progress in their studies, as we maintain in the present study.

A wide range of valid methods have been used to measure self-regulation and their design depends on their authors' theoretical principles, such as e.g. Román and Gallego's ACRA (2008), which evaluates four main learning strategy categories (acquisition, codification, recuperation or evaluation of information and support for its processing). Some authors, such as Pintrich (2004) use the same questionnaires as those used to measure learning approaches (MSLQ) (García, 2012), which consists of 81 items. In the present study we used the Self-Regulation Questionnaire for Academic Learning (Torre, 2007). This covers four factors or self-regulation dimensions and has the great advantage of being easier to use than the other models (20 items).

According to García-Jiménez (2015), the universities ought to suggest learning strategies to promote the students' own self-regulated learning. For example, De la Cruz and Abreu (2014) proposed a methodological strategy for self-regulation based on the use of rubrics, while feedback is another possibility that gives meaning to evaluations. This is the information obtained from evaluations that students can use to reduce the difference between the results actually obtained and those expected.

In practice, good feedback (to improve self-regulation) can be defined as anything that reinforces the students' capacity to self-regulate their own performance. Nicol and Macfarlane-Dick (2006) laid down seven principles that feedback must have:

- Help to clarify what good performance is (goals, criteria, and expected standards).

- Help to develop self-evaluation (reflection) in learning.

- Provide quality information to students on their learning.

- Encourage student/teacher dialogue in learning.

- Foment positive motivational beliefs and self-esteem.

- Give the opportunity to close the gap between the obtained and the desired performance.

- Give the teacher useful information to improve his teaching.

Based on some author's recommendations (Boud \& Molloy, 2013), Gallego, Quesada, Gómez and Cubero (2017) compiled a series of conditions for the feedback process to promote self-regulation and strategic learning and underline the importance of student participation. This has opened up new areas to explore, such as pair-based self-evaluation (García-Jiménez, Gallego-Noche \& Gómez-Ruíz, 2015).

Many studies use feedback activities to show their positive effect on students' self-regulation and their indirect effect on their academic performance. Nicol (2009) studied the re-design of the first university 
years by incorporating feedback and formative evaluation, resorting to technological support due to the large numbers of students involved. These re-designs improved the performance in final exams over the previous years and significantly increased student satisfaction in all aspects related to the activities. The studies by Llorens, Vidal-Abarca and Cerdán (2016) and Gallego et al. (2017) explored the same field.

In this context and due to the situation of the subject used in the study, the question arises as to whether there is any way of encouraging students to self-regulate and be conscious of the fact that to assimilate this subject it is not enough to simply study for a short period before an exam, but it requires a continuous weekly effort throughout the year. Is it possible to promote self-regulation and strategic learning by any practical method? Interest in feedback and its link with self-regulated learning has grown in recent years (Gallego et al., 2017; García-Jiménez et al., 2015; Garello \& Rinaudo, 2013; Labuhn, Zimmerman \& Hasselhorn, 2010; Llorens et al., 2016). In studies carried out in universities, feedback together with student participation in evaluations, "is considered to be an essential process for learning and the development of students' self-regulation in comparison with any other aspect of teaching" (Gallego et al., 2017). According to Labuhn et al. (2010) the feedback can come from the student himself, from classmates or from teachers. After receiving it, "the student makes a kind of comparison between the initial goal and his real performance (a key process in the self-regulation cycle) and reflects on, revises and optimises what he has learned (Garello \& Rinaudo, 2013).

Other studies have found that students that self-regulate cognitive, motivational and behavioural aspects of their academic performance are more effective learners. Herndon and Bembenutty (2017) found that academic performance was significantly related to self-regulation and other factors such as intrinsic motivation and self-efficiency. Alegre (2014) obtained a significant positive relationship in first year undergraduates between self-regulation, self-efficiency and academic performance.

Elvira-Valdés and Pujol (2012) found moderate levels of self-regulation in university students and small differences by gender in favour of females. The positive relationship between the matriculation and the final grades obtained suggest a relationship between previous academic performance and academic success according to grades.

In Nota, Soresi and Zimmerman (2004), high school students' cognitive self-regulation, organisational and transformational strategy in their final years was found to be a significant predictor of their yearly grades and other average grades in later years and in university exams, while their motivational self-regulation strategy was a significant predictor of diploma and secondary grades and their intention to continue in education after secondary school. Zimmerman and Kitsantas (2014) obtained good predictions of the academic performance of 507 secondary school students from a series of measurements to estimate their degree of self-regulation. There were no significant differences in either variable as regards gender.

The design of pre-test-post-test experiments (Salkind, 2010) that compare variables before and after treatment by pre- and post-treatment questionnaires, as in the present work, is a normal research method and is frequently used in education. The aim is usually to measure the effect of a treatment on a certain group and has been used in the studies by Bachiochi, Everton, Evans, Fugere, Escoto, Letterman et al. (2011), Hall, Ramsay and Raven (2004), De Andrés (2019) and Romero and Gómez (2019) in the field of education in general, and in those by Degani, Rajendrakumar, Smith and Grimsley (2009), Dobson, Stevenson, Busch, Scott, Henry and Wall (2009) and Goldstein, Helenius, Foldes, McGinn and Korenstein (2005) with medical students.

The term self-regulation is closely related to other terms that start with the prefix "self" (self-control, selfmanagement, self-directed behaviour and self-discipline). Morosanova, Tyganov, Vanin and Philippova (2014) found a significant negative correlation between self-regulation and the level of students' anxiety and annoyance, and a positive one between their levels of self-regulation and curiosity. 
The first-year subjects are coordinated in such a way that every Monday there is an evaluation in one of them. Although the evaluations are equally shared out between the subjects, the system has the disadvantage that the students spend most of their time preparing for the following Monday's exam.

The subject under study in the present work is highly practical in terms of its contents and spatial vision skills and requires the continual exercise of functional gymnastics. Besides the weekly face-to-face and virtual exercises and practices, different evaluations take place throughout the year (see chronological sequence in Figure 1). There are 5 practical cases (CP1, CP2, CP3, CP4 and CP5), which make up 40\% of the final grade, and two partial exams (P1 and P2), which represent the remaining 60\%. In several years it has been found, and has been recognized by the students themselves, that they do not really start to work on the subject until the approach of the first relatively important evaluation (P1). Before this exam, there have been others (CP1, CP2 and CP3), which normally produce fairly unsatisfactory results.

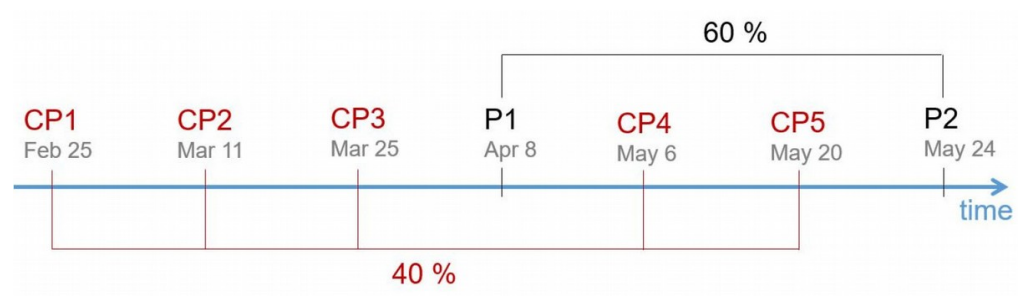

Figure 1. Distribution and relative value of evaluations throughout the year $(\mathrm{CP}=$ practical cases, $\mathrm{P}=$ partial exams $)$

This starting situation, as well as the preliminary results of this research are described in Navarro (2019). In this study we designed a self-feedback activity for students to carry out their own self-diagnosis and provide their own feedback immediately after getting the results of CP1 and CP2. The aim was to get them to devote time to the subject from the beginning with in-depth knowledge and the ability to apply its concepts before the first partial exam (P1). Llorens et al. (2016) claim that the most effective feedback is not limited to information on the correct answer only, in the sense that the first option makes it easy to compare the result and the desired standard and frees the mechanisms to re-direct the students' strategies and behaviour.

\subsection{Objectives}

The aim of the study was to determine whether the proposed self-feedback mechanism would have a positive effect on the students' self-regulation and their academic performance. The research question considered was therefore: Does self-feedback improve students' self-regulation?

The hypotheses were as follows:

1. Self-feedback improves self-regulation (H1).

2. There is no significant gender difference in the students' self-regulation capacity (H2).

3. The students who choose the degree course as their first or second option have a greater degree of self-regulation and obtain higher final grades (H3).

4. The students with the best matriculation grades have the best self-regulation and academic performance (H4).

5. The students with the best class attendance have a greater degree of self-regulation and better academic performance (H5).

To sum up, the objective of the study was to make the students capable of developing and/or improving their ability for self-regulation by means of self-feedback activities to improve their quality of learning and thus also their academic performance. 


\section{Method}

This section describes the materials used and the research method followed. This can be seen in Figure 2, which gives details of the series of actuations carried out. The experiment was a type of pre-test-post-test and measured the effectiveness of the self-regulation treatment.

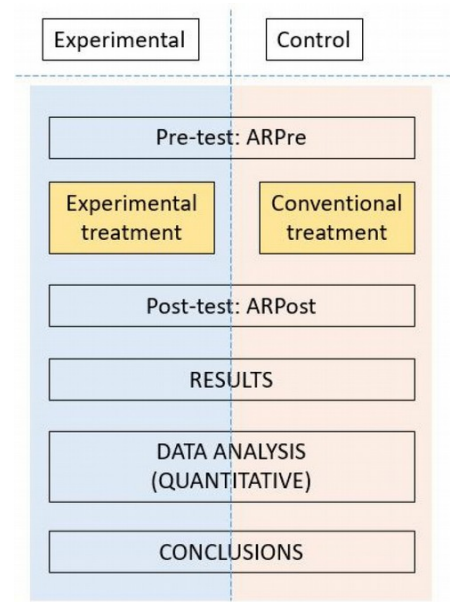

Figure 2. Research method

\subsection{Participants}

The students were divided into two practice sub-groups: G1 (experimental group $E G, N=22$ ) and G2 (control group $\mathrm{CG}, \mathrm{N}=18$ ). However, due to administrative reasons and the treatment dropout rate (see Conclusions) the numbers in practice were $\mathrm{N}=12$ in $\mathrm{EG}$ and $\mathrm{N}=28$ in CG.

The same method was applied to both groups during the year, except for the experimental treatment given to EG, which consisted of two self-feedback activities during the year (see the Self-Regulation Treatment section).

\subsection{Variables studied}

Variables considered in the study are shown in Table 1.

\begin{tabular}{|c|c|c|}
\hline Variable & Values & Name \\
\hline Sex & Male/Female & SEX \\
\hline Matriculation grade & $5-14$ & NACC \\
\hline Studied technical drawing at secondary school & YES / NO & $\mathrm{BACH}$ \\
\hline Preference for degree course & $\begin{array}{l}1 \text { (1st or } 2 \text { nd), } 2 \text { (3rd or } \\
\text { later) }\end{array}$ & OPT \\
\hline Self-feedback activity carried out & $\begin{array}{l}\text { YES (Experimental Group) } \\
\text { NO (Control Group) }\end{array}$ & ACT \\
\hline Self-regulation capacity at beginning of year & $0-100$ & ARPre \\
\hline Self-regulation capacity at end of year & $0-100$ & ARPost \\
\hline $\begin{array}{l}\text { Pre- and Post-test scores in the four factors that } \\
\text { compose self-regulation }\end{array}$ & $0-5$ & $\begin{array}{c}\text { FIPre, FIIPre, FIIIPre, } \\
\text { FIVPre, FIPost, PIIPost, } \\
\text { FIIIPost, FIVPost }\end{array}$ \\
\hline Grades obtained in practical cases & $0-10$ & PC1, PC2, PC3, PC4, PC5 \\
\hline Grades obtained in partial exams & $0-10$ & P1, P2 \\
\hline $\begin{array}{l}\text { Final grade in the subject, a linear combination of grades } \\
\text { of two practical cases }(40 \%) \text { and partial exams }(60 \%)\end{array}$ & $0-10$ & QF \\
\hline Class attendance & $0-100$ & ASIST \\
\hline
\end{tabular}

Table 1. Variables studied 


\subsection{Instruments}

The Questionnaire on Self-Regulation for Academic Learning (Torre, 2007), based on Zimmerman \& Pintrich's theory of self-regulation processes in motivation with a cognitive focus, was used to measure the students' level of self-regulation before and after the treatment. The questionnaire consisted of 20 items on a Likert Scale from 1 to 5 points on four different factors (see Table 2).

\begin{tabular}{|l|c|}
\hline \multicolumn{1}{|c|}{ Factor } & Items \\
\hline FI: Active meta-cognitive awareness & $3,6,7,8,13,20$ \\
\hline FII: Control and verification & $1,2,4,12,14,15,18$ \\
\hline FIII: Daily effort in carrying out tasks & $5,9,10,11$ \\
\hline FIV: Active processing during classes & $16,17,19$ \\
\hline
\end{tabular}

Table 2. Dimensional factors of Torres' questionnaire on self-regulation for academic learning (2007)

Its psychometric properties earned a Cronbach's $\alpha$ of $0.86(\mathrm{M}=74.50$; $\mathrm{DE}=9.589)$ based on the scores of 1188 university students at the Universidad Pontificia de Comillas. Evidence of validity was obtained by analyzing the correlation with other variables such as study focus (deep $\mathrm{r}=0.564, \mathrm{p}<0.01$; achievement $\mathrm{r}=0.531, \mathrm{p}<0.01)$ and academic self-sufficiency $(\mathrm{r}=0.482, \mathrm{p}<0.01)$.

The pre-treatment questionnaire had three added questions to obtain the data on the matriculation grades (NACC,), the students' order of preference for the degree being studied (OPT), and the BACH variable (previous studies in technical drawing in secondary school).

The academic performance variables were obtained from the lecturer's notes. Those considered are given in Table 1. Stratgraphics Centurión XVII software was used for the quantitative data analysis

\subsection{Self-Regulation Treatment}

The treatment was carried out twice a year in Practical Cases 1 and 2 (see Figure 1). The results of CP1 were sent to the students but the solution of the practical case was not published. The first self-regulation activity was then carried out. This consisted of:

- The students were given a photocopy of their (uncorrected) exercise and were asked to write a brief report on their mistakes with some comments on the correct solution and what they thought they should have done. They were not asked to repeat the exercise. All the reports were published in the teacher-lecturer's shared space in the university's PoliformaT platform.

- The students later defended their reports in a brief tutorial with the lecturer.

- To encourage their participation in this activity, those who satisfied the requirements for compiling and defending their self-evaluation reports could raise their CP1 grade by up to 3 points.

The same process was repeated in CP2 with the only difference that it took place online (with computer-assisted design) and the exercises were saved on the university's free-access educational platform for the students to analyse and write their self-feedback report.

\subsection{Data Analysis}

The first descriptive statistical analysis was made to study the students' self-feedback behaviour and the variables associated with it.

To obtain a general impression of the degree of the linear relationship and how the quantitative variables interacted with each other (especially self-regulation and academic performance) a correlation analysis was performed applying Pearson's correlation coefficient. Variance analyses were used to evaluate the effect of self-feedback and other variables on the students' pre- and post-treatment self-regulation capacity as follows: 


\section{ANOVA 1}

$$
\text { ARPre }=\mu+A C T i+S E X i+O P T i+B A C H i+N A C C i+E
$$

To determine the students' level of self-regulation at the beginning of the year.

\section{ANOVA 2}

$$
A R P o s t=\mu+A C T i+S E X i+O P T i+B A C H i+N A C C i+A S I S T i+E
$$

To determine the students' level of self-regulation after the treatment.

\section{ANOVA 3}

$$
\operatorname{Inc} A \mathrm{R}=\mu+A C T i+S E X i+O P T i+B A C H i+N A C C i+A S I S T i+E
$$

To determine the students' pre- and post-treatment self-regulation evolution.

\section{ANOVA 4}

To analyse the final grade variable according to self-feedback activity, sex, degree preference option, study of technical drawing at secondary school, and the co-variables - matriculation grade, class attendance and pre- and post-treatment self-regulation.

$$
Q F=\mu+A C T i+S E X i+O P T i+B A C H i+N A C C i+A S I S T i+A R P r e i+A R P o s t i+E
$$

\section{Results and Discussion}

The students' average score in the self-regulation pre-test was $71.26 \%$ and $71.03 \%$ in the post-test. These values are similar to or slightly lower than those found in the same test used in other studies, e.g. Barahona (2014) (72.6), Alegre (2014) (73.15) and Torre (2006) (74.50), with similar SDs. There was no significant difference between the pre- and post-treatment results.

The self-regulation increment variable was negatively related to the pre-self-regulation $(\mathrm{r}=-0.37 ; \mathrm{p}<0.05)$ and positively with the post-self-regulation $(\mathrm{r}=0.49 ; \mathrm{P}<0.05)$, i.e. those with the least initial self-regulation increased most, while those who increased most had the highest final self-regulation. Both these relationships seem logical, although the final balance is the fact that there was no increase in selfregulation between the pre- and post-tests.

Figure 3 gives the scores for factors FI (active meta-cognitive awareness), FII (control and verification) and FIV (active processing in class) of self-regulation in the pre- and post-test.

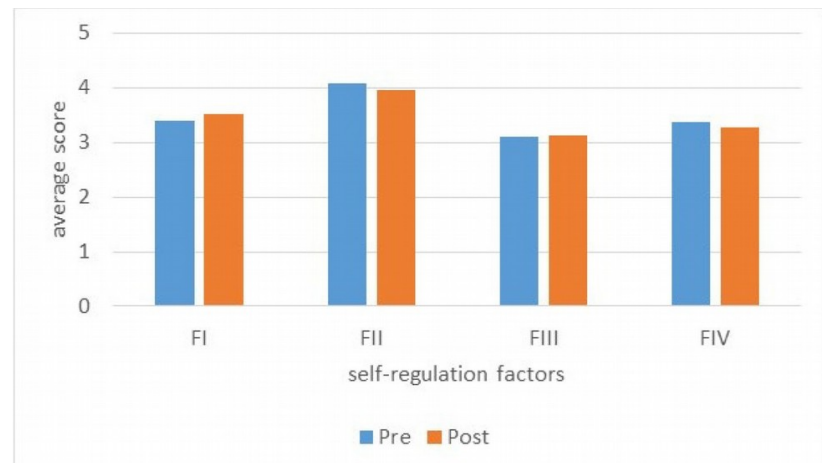

Figure 3. Average score of self-regulation factors (FI - active meta-cognitive awareness, FII - control and verification, FIII - daily effort in tasks, FIV - active processing in class) 
The order of the factor results also coincides with that of other studies (Barahona, 2014). Factor II had the highest score in general, while factor III (daily effort) had the lowest. This confirms the statement in the Introduction to the effect that the students do not devote daily time and effort to the subject from the beginning of term.

\subsection{Hypothesis 1}

The ANOVA 1 and 3 analyses showed that auto-feedback has a statistically significant effect $(\mathrm{p}<0.05)$ on both higher self-regulation and on the self-regulation score in the post-test (see Figure 4). Average post self-regulation of the experimental group was 78.50 vs. 66.47 in the control. The increase in self-regulation between the beginning and end of the year (pre and post) was 2.76 points in the experimental and -4.58 in the control group, which confirms the first hypothesis (self-feedback treatment improves self-regulation).

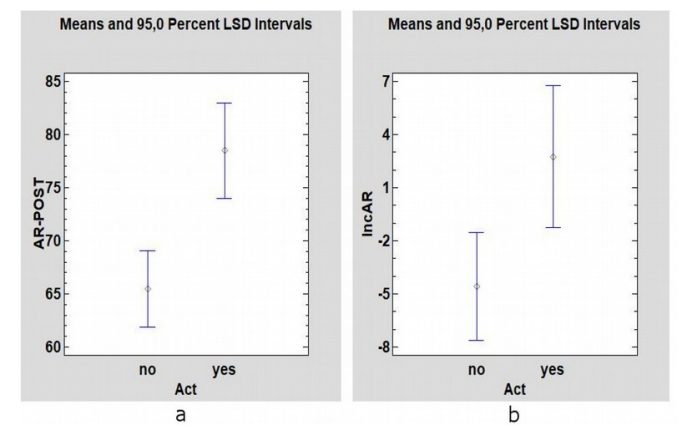

Figure 4. Effect of self-feedback activity on the post self-regulation (a) and increased self-regulation (b)

\subsection{Hypothesis 2}

The analysis of variance also confirmed the second hypothesis: no relationship was found between gender and the self-regulation and self-regulation increment scores.

\subsection{Hypothesis 3}

The order of preference of the degree course had a significant effect on the self-regulation post-test score $(\mathrm{p}<$ 0.05) (ANOVA 2) (Figure 5b) and confirmed the first part of Hypothesis 3. Students whose first or second choice was the engineering degree had higher average scores than those who placed it in third place or more (76.24 vs. 67.72). This was also found in the pre-test (75.49 vs. 67.32) (ANOVA 1), although in this case the difference was not significant $(\mathrm{p}=0.08)$ (Figure $5 \mathrm{a})$. The reason for this could lie in the close relationship between self-regulation and the deep learning styles, and thus with a "higher degree of emotional, personal and academic maturity”, as pointed out by Alonzo, Valencia, Vargas, Bolívar and García (2016).

The order of degree preference was not found to influence the final grade in the subject (ANOVA 4), which confirms the first part of Hypothesis 3, but not the second.
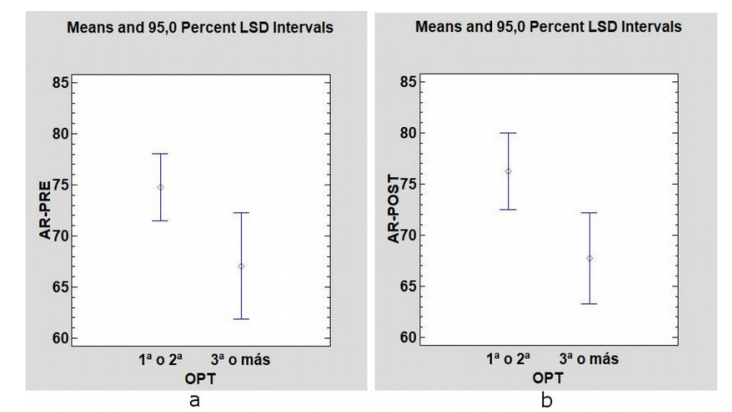

Figure 5. Effect of OPT (Option) factor on pre (a) and post (b) self-regulation 


\subsection{Hypothesis 4}

The analysis of variance showed that the matriculation grade had no significant effect on the final grade or on the pre- and post-treatment score, but was negatively related $(\mathrm{r}=-0.40 ; \mathrm{p}<0.05)$ to higher self-regulation $(\mathrm{p}<0.05)$ and thus discounted the fourth hypothesis. This means that students with the highest matriculation grades have the lowest increase in self-regulation and are not necessarily those who have the highest self-regulation either at the beginning or the end of the year, nor do they obtain the highest marks. This agrees with the findings of Gargallo, Suárez, García, Pérez and Sahuquillo (2012): "Excellence or high matriculation grades are related to deeper learning approaches, although they have not been shown to be related to self-regulation."

However, a small significant correlation $(\mathrm{r}=0.33 ; \mathrm{p}<0.05)$ was found between matriculation grade and self-regulation Factor III in the pre-test, related to daily effort in academic tasks, indicating that the students with the highest matriculation grades are more accustomed to daily efforts.

\subsection{Hypothesis 5}

The class attendance variable behaved similarly to the matriculation grade and was not found to have a significant effect on the pre- and post-test scores, which meant the first part of the fifth hypothesis could not be confirmed. However, it did have an influence on the self-regulation increment between the pre- and post-test $(\mathrm{r}=0.43 ; \mathrm{p}<0.05)$. The students that achieved the most improvement in self-regulation were those with the best class attendance marks.

The final subject grade was also significantly influenced by class attendance in ANOVA 4 and this was confirmed by the relation between both factors $(\mathrm{r}=0.60 ; \mathrm{p}<0.05)$. This confirmed the second part of the fifth hypothesis. Those with the best class attendance obtained the highest final grades and also the highest scores in $\mathrm{CP} 1(\mathrm{r}=0.43 ; \mathrm{p}<0.05)$. In fact, those who obtained the highest $\mathrm{CP} 1$ scores were the ones that least required the auto-feedback activity.

To sum up, the arrows in Figure 6 represent the significant relationships mentioned above. Auto-feedback is related to the self-regulation increment and to the self-regulation achieved by the end of the year, which is both desirable and positive, but is not reflected in a better end-of-year mark in the subject, which was influenced solely by class attendance. An association was found between class attendance and the activity: those who took part had significantly better class attendance $(82.2 \%)$ than those who did not $(68.6 \%)$ $(\mathrm{p}<0.05)$.

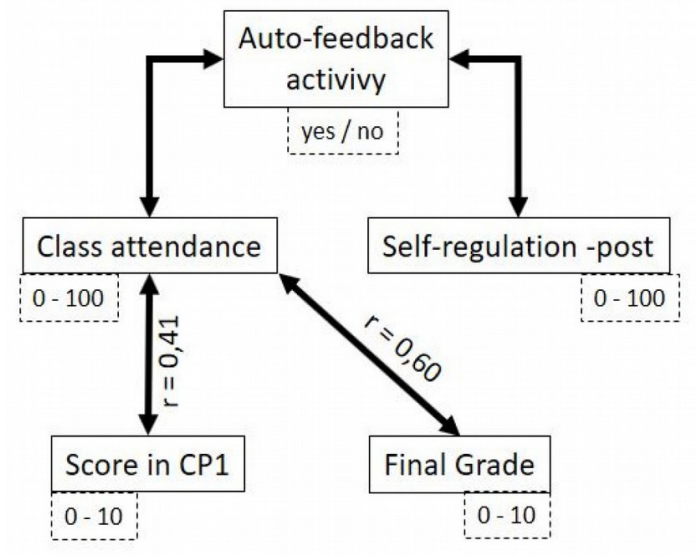

Figure 6. Significant relationships between posttreatment self-regulation and auto-feedback. Arrows indicate a significant effect in the analysis of variance and/or correlation and dotted lines the range of the variable 
It can therefore be said that the auto-feedback activity is related to the final grade through the class attendance variable, although somewhat indirectly. In fact, if the experimental group's average final grades (6.97) are isolated and compared with those of the control group (3.80) they are found to be significantly different ( $\mathrm{p}<0.05$ ). Following in the line of previous studies (Alegre, 2014; Schunk, 2012), the possibility arises of completing this work by also including the academic self-efficacy factor.

\section{Conclusions}

The results obtained show that auto-feedback improves students' self-regulation capacity.

The students that took part in the activity were also those with the best class attendance, while these latter students obtained the highest end-of-year grades. Due to the nature of this subject, it is important to make the students aware of the need to attend classes from the beginning of term in order to obtain academic success. This can be demonstrated by the relationship obtained between attendance and the final grades and the low Factor III scores (effort applied to daily tasks) and was confirmed by the lecturers' opinion (these results will be included in a future qualitative analysis). Class attendance includes both theoretical and practical classes, since the subject mostly involves practical skills and none of the classes are entirely theoretical. All of this corroborates what has been previously explained about the need for a progressive and continuous effort right from the start in the subject.

Another possible line of study is to determine whether auto-feedback has a direct influence on the grades obtained by means of improved self-regulation.

The possible limitations of this study include the dropout rate of the experimental group, which was reduced from the original 22 to only 12 participants. The small incidence of the activity on the subject grade ( 0.5 out of 10$)$ could have had an influence on this low participation. It is hoped to carry out future studies along these lines with larger samples and students from other degree courses and/or universities to confirm the relationship between academic performance and self-regulation, or possibly incorporate the auto-efficacy variable. It will also be necessary to improve the definition of the activities offered to the students to reduce the dropout rate and make the activity an integral part of the subject and with a higher weight in the final grade.

The relationship found between the preference for the degree and the level of auto-regulation should also be noted. This corroborates the revision of the learning theories that closely link self-regulation and motivation: "Processes such as laying down goals, auto-efficacy and expected results are important motivational variables that influence self-regulation" (Schunk, 2012).

No relationship was found between matriculation grades and self-regulation, although there was a relationship with its Factor III. Even though the students with the best matriculation grades are shown to be more accustomed to daily effort in their tasks (Factor III) it does not seem to be an advantage in their university studies as it is not reflected in greater self-regulation or higher final grades. All of this is related to the complex process of moving from the secondary school to the university, where the students require a much higher level of autonomy and responsibility.

The capacity for self-regulation can be fomented in students by diverse means, for example by the study and development of specific contextualised strategies such as the auto-feedback activity described in this work. The role of the lecturers as models for the students in putting their own self-regulation strategies into practice in the classrooms should also be remembered.

We hope to continue developing experiences in this line in the context of this study, always remembering that fomenting cognitive, meta-cognitive and personal self-regulation strategies have an effect not only on academic performance but also on developing the students' competences in quality learning. 


\section{Declaration of Conflicting Interests}

The author declared no potential conflicts of interest with respect to the research, authorship, and/or publication of this article.

\section{Funding}

The author received no financial support for the research, authorship, and/or publication of this article.

\section{References}

Alegre, A. (2014). Autoeficacia académica, autorregulación del aprendizaje y rendimiento académico en estudiantes universitarios iniciales. Propósitos y Representaciones, 2(1), 79-120.

http://doi.org/10.20511/pyr2014.v2n1.54

Alonzo, D.L., Valencia, M.C., Vargas, J., Bolivar, N.J., \& Garcia, M.J. (2016). Los estilos de aprendizaje en la formación integral de los estudiantes. Revista Boletín Redipe, 5(4), 109-114.

https://revista.redipe.org/index.php/1/article/view/105

Barahona, M. (2014). Correlación entre autoeficacia, autorregulación y rendimiento académico en los estudiantes de 4to. y 5to. Bachillerato del colegio san Francisco Javier de la Verapa: Tesis doctoral. Guatemala: Universidad Rafael Landívar, Campus Central.

Bachiochi, P., Everton, W., Evans, M., Fugere, M., Escoto, C., Letterman, M., et al. (2011). Using empirical article analysis to assess research methods courses. Teaching of Psychology, 38(1), 5-9.

https://doi.org/10.1177/0098628310387787

Boekaerts, M., \& Corno, L. (2005). Self-regulation in the classroom: a perspective on assessment and intervention. Applied Psychology, 54(2), 199-231. https://doi.org/10.1111/j.1464-0597.2005.00205.x

Boud, D., \& Molloy, L. (2013). Feedback in Higher and Professional Education (1st ed). London: Routledge. https://doi.org/10.4324/9780203074336

De Andrés, D. (2019). Facilitando la autorregulación del aprendizaje en el diseño desistemas digitales. IN-RED 2019: V Congreso de Innovación Educativa y Docencia en Red. http://doi.org/10.4995/INRED2019.2019.10430

Degani, A.T., Rajendrakumar, M., Smith, B.E. \& Grimsley, E. (2009). The Effect of Student Training on Accuracy of Completion of Death Certificates. Medical Education Online, 14(1).

https://doi.org/10.3402/meo.v14i.4510

De la Cruz, G., \& Abreu, L.F. (2014). Rúbricas y autorregulación: pautas para promover una cultura de la autonomía en la formación profesional. REDU. Revista de Docencia Universitaria, 12(1), 31-48. https://doi.org/10.4995/redu.2014.6429

Dobson, R.T., Stevenson, K., Busch, A., Scott, D.J., Henry, C., \& Wall, P.A. (2009). A Quality Improvement Activity to Promote Interprofesional Collaboration Among Health Professions Students. American Journal of Pharmaceutical Education, 73(4), 1-7. https://doi.org/10.5688/aj730464

Elvira-Valdés, M.A., \& Pujol, L. (2012). Autorregulación y rendimiento académico en la transición secundaria-universidad. Revista Latinoamericana de Ciencias Sociales, Niñezy Juventud, 10(1). http://www.redalyc.org/articulo.oa?id=77323982022

Gallego, B., Quesada, V., Gómez, M., \& Cubero, J. (2017). La evaluación y retroalimentación electrónica entre iguales para la autorregulación y el aprendizaje estratégico en la universidad: la percepción del alumnado. REDU. Revista de Docencia Universitaria, 15(1), 127-146. https://doi.org/10.4995/redu.2017.5991 
García, M. (2012). La autorregulación académica como variable explicativa de los procesos de aprendizaje universitario. Profesorado. Revista de currículum y formación del profesorado, 16(1), 203-221.

García, M., \& Jiménez, A. (2014). Estrategias en el aprendizaje de la lengua extranjeray niveles de competencia en estudiantes universitarios de magisterio. Revista deInvestigación Educativa, 32(2), 363-378. http://doi.org/10.6018/rie.32.2.167421

García-Jiménez E., Gallego-Noche B., \& Gómez-Ruíz, M.Á. (2015). Feedback and self-regulated learning: how feedback can contribute to increase students' autonomy as learners. In: Peris-Ortiz, M., Merigó, J. (eds) Sustainable Learning in Higher Education. Innovation, Technology, and Knowledge Management (113-130). Cham: Springer. https://doi.org/10.1007/978-3-319-10804-9_9

García-Jiménez, E. (2015). La evaluación del aprendizaje: de la retroalimentación a la autorregulación. El papel de las tecnologías. Revista electrónica de investigación y evaluación educativa, 21(2). http://doi.org/10.7203/relieve.21.2.7546

Garello, M.V., \& Rinaudo, M.C. (2013). Autorregulación del aprendizaje, feedback y transferencia de conocimiento. Investigación de diseño con estudiantes universitarios. Revista Electrónica de Investigación Educativa, 15(2), 131-147. http://redie.uabc.mx/vol15no2/contenido-garellorinaudo.html

Gargallo, B., Suárez, J.M., García, E., Pérez, C. \& Sahuquillo, P.M. (2012). Enfoques de aprendizaje en estudiantes universitarios excelentes y en estudiantes medios. Revista española de pedagogía, 252, 185-200. https://revistadepedagogia.org/wp-content/uploads/2012/05/252-01.pdf

Goldstein, C.E., Helenius, I., Foldes, C., McGinn, T., \& Korenstein, D. (2005) Internists Training Medical Residents in Pelvic Examination: Impact of an Educational Program. Teaching and Learning in Medicine, 17(3), 274-278. https://doi.org/10.1207/s15328015tlm1703_13

Gravini-Donado, M., Ortiz-Padilla, M.E., \& Campo-Ternera, L.A. (2016). Autorregulación para el aprendizaje en estudiantes universitarios. Educación Y Humanismo, 18(31), 326-342.

https://doi.org/10.17081/eduhum.18.31.1382

Hall, M., Ramsay, A., \& Raven, J. (2004). Changing the learning environment to promote deep learning approaches in first-year accounting students. Accounting Education, 13(4), 489-505. https://doi.org/10.1080/0963928042000306837

Hernández, A., \& Camargo, A. (2017). Autorregulación del aprendizaje en la educación superior en Iberoamérica: una revisión sistemática. Revista Latinoamericana de Psicologia, 49(2), 146-160. https://doi.org/10.1016/j.rlp.2017.01.001

Hernández, F., Rosário, P., Cuesta, J., Martínez, P., \& Ruiz, E. (2006). Promoción del aprendizaje estratégico y competencias de aprendizaje en estudiantes de primero de universidad: Evaluación de una intervención. Revista de Investigación Educativa, 24(2), 615-631.

Herndon, J.S., \& Bembenutty, H. (2017). Self-regulation of learning and performance among students enrolled in a disciplinary alternative school. Personality and Individual Differences 104, 266-271. https://doi.org/10.1016/j.paid.2016.08.027

Labuhn, A.S., Zimmerman, B.J., \& Hasselhorn, M. (2010). Enhancing students' self-regulation and mathematics performance: the influence of feedback and self-evaluative standards. Metacognition Learning 5, 173-194. https://doi.org/10.1007/s11409-010-9056-2

Limón, M. (2004). Cambio conceptual y el aprendiz intencional esbozado por Paul R. Pintrich. Revista Electrónica de Investigación Psicoeducativa, 2(1), 175-184. 
Llorens, A.C., Vidal-Abarca, E., \& Cerdán, R. (2016). Formative feedback to transfer self-regulation of task-oriented reading strategies. Journal of Computer Assisted Learning, 32, 314-331.

https://doi.org/10.1111/jcal.12134

López, A., López-Aguado, M., González, I., \& Fernández, E. (2012). El ocio y los enfoquesde aprendizaje en estudiantes universitarios de Enfermería. Revista de Investigación Educativa, 30(1), 53-70.

https://doi.org/10.6018/rie.30.1.111581

Morosanova, V., Tsyganov, I., Vanin, A., \& Philippova, E. (2014). Self-regulation of learning activity and its relationship with individual differences of high school students. Personality and Individuals Differences, 60, Suplement, S69. https://doi.org/10.1016/j.paid.2013.07.304

Navarro, J.M. (2019). Comienzo de los alumnos en la Universidad: autorregulación yprimeros resultados. IN-RED 2019: V Congreso de Innovación Educativa y Docencia en Red. http://dx.doi.org/10.4995/INRED2019.2019.10464

Nicol, D. (2009). Assessment for learner self-regulation: enhancing achievement in the first year using learning technologies. Assessment \& Evaluation in Higher Education, 34(3), 335-352. https://doi.org/10.1080/02602930802255139

Nicol, D.J., \& Macfarlane-Dick, D. (2006). Formative assessment and self-regulated learning: a model and seven principles of good feedback practice. Studies in Higher Education, 31(2), 199-218.

https://doi.org/10.1080/03075070600572090

Nota, L., Soresi, S., \& Zimmerman, B.J. (2004). Self-regulation and academic achievement and resilience: A longitudinal study. International Journal of Educational Research, 41(3), 198-215.

https://doi.org/10.1016/j.ijer.2005.07.001

Núñez, J.C., Rosário, P., Vallejo, G., \& González-Pienda, J.A. (2013). A longitudinal assessment of the effectiveness of a school-based mentoring program in middle school. Contemporary Educational Psychology, 38(1), 11-21. https://doi.org/10.1016/j.cedpsych.2012.10.002

Panadero, E., \& Alonso-Tapia, J. (2014). Teorías de autorregulación educativa: una comparación y reflexión teórica. Psicología Educativa 20(1), 11-22. https://doi.org/10.1016/j.pse.2014.05.002

Pintrich, P.R. (2004). A conceptual framework for assessing motivation and elfregulated learning in College students. Educational Pshychology Review, 16(4), 385-407. https://doi.org/10.1007/s10648-004-0006-x

Román, J.M., \& Gallego, S. (2008). ACRA. Escalas de Estrategias de Aprendizaje (Manual) (4a ed.). Madrid: TEA Ediciones.

Romero, A., \& Gómez, J. (2019). Enfoques de aprendizaje, autorregulación y autoeficacia y su influencia en el rendimiento académico en estudiantes universitarios de Psicología. European Journal of Investigation in Health, Psychology and Education, 9(2), 95-107. https://doi.org/10.30552/ejihpe.v9i2.323

Rosário, P., Fuentes, S., Beuchat, M., \& Ramaciotti, A. (2016). Autorregulación del aprendizaje en una clase de la universidad: un enfoque de infusión curricular. Revista de Investigación Educativa, 34(1), 31-49. http://doi.org/10.6018/rie.34.1.229421

Rosário, P., Núñez, J.C., González-Pienda, J.A., Valle, A., Trigo, L., \& Guimarães, C.(2010). Enhancing self-regulation and approaches to learning in first-year college students: A narrative-based program assessed in the Iberian Peninsula. European Journal of Psychology of Education, 25(4), 411-428. https://doi.org/10.1007/s10212-010-0020-y

Salkind, N. (2010). Encyclopedia of research design. Thousand Oaks: SAGE Publications Ltd. http://doi.org/10.4135/9781412961288.n331 
Schunk, D. (2012). Teorías del aprendizaje: Una perspectiva educativa (6th ed.). México, D.F.: Pearson.

Sinatra, G. (2004). Contribuciones de Paul R. Pintrich a la investigación sobre cambio conceptual. Revista Electrónica de Investigación Psicoeducativa, 2(1), 171-174.

Torre, J.C. (2006). La autoeficacia, la autorregulación y los enfoques de aprendizaje en estudiantes universitarios. Tesis doctoral. Universidad Pontificia Comillas. Madrid.

Torre, J.C. (2007). Una triple alianza para un aprendizaje universitario de calidad. Madrid: Universidad Pontificia de Comillas.

Vives-Varela, T., Durán-Cárdenas, C., Varela-Ruiz, M., \& Fortoul, T. (2014). La autorregulación en el aprendizaje, la luz de un faro en el mar. Investigación en Educación Médica, 3(9), 34-39. https://doi.org/10.1016/S2007-5057(14)72723-1

Zimmerman, B.J. (2002). Becoming a self-regulated learner: An overview. Theory into Pratice, 41(2), 64-70. https://doi.org/10.1207/s15430421tip4102_2

Zimmerman, B.J., \& Kitsantas, A. (2014). Comparing students' self-discipline and self-regulation measures and their prediction of academic achievement. Contemporary Educational Psychology 39(2), 145-155.

https://doi.org/10.1016/j.cedpsych.2014.03.004

Published by OmniaScience (www.omniascience.com)

Journal of Technology and Science Education, 2021 (www.jotse.org)

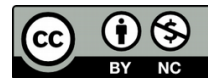

Article's contents are provided on an Attribution-Non Commercial 4.0 Creative commons International License. Readers are allowed to copy, distribute and communicate article's contents, provided the author's and JOTSE journal's names are included. It must not be used for commercial purposes. To see the complete licence contents, please visit https://creativecommons.org/licenses/by-nc/4.0/. 